\title{
CHANGES IN THE MASS AND CHEMICAL COMPOSITION OF THE GASTROINTESTINAL TRACT AND LIVER OF DUCKS IN THE FIRST TWO MONTHS AFTER HATCHING
}

\author{
EVA BARANYIOVÁ, A. HOLUB and EMILIE PONÍŽILOVÁ \\ Department of Physiology, University of Veterinary Science, 61242 Brno, \\ Department of Veterinary Prevention, University of Agriculture, 66265 Brno
}

Received October 10, 1980

\begin{abstract}
Baranyiová Eva, A. Holub, Emilie Ponížilová: Changes in the Mass and Chemical Composition of the Gastrointestinal Tract and Liver of Ducks in the First Two Months after Hatching. Acta vet. Brno, 52, 1983: 39-47.

Quantitative changes and chemical composition of the individual digestive organs and liver were investigated in 90 White Pekin ducks from hatching to 56 days of age.

The greatest live body mass increase was found in the fourth and fifth weeks whereas the actual mass of the whole gastrointestinal tract (GIT) grew most rapidly in the third week and that of the liver in the second week. The greatest contribution to the GIT growth rate was that of the intestines followed by the gizzard. The contributions of the eso ?hagus, crop and proventriculus were small.

Despite of its great increase in mass the GIT showed a fairly constant relative water and protein content but its fat content, especially in the intestine and liver, was sharply decreased by the end of the first posthatching week.

The actual gross energy content of the investigated organs increased to different degrees; an almost 40 fold increase was observed in the GIT but only a 20 fold in the liver. The small increase in gross energy content of the liver was accounted for by low increase in its fat but also glycogen amounts. Consequently, the importance of the liver as a readily available energy reserve for ducklings declines with their advancing age.
\end{abstract}

Protein, fat, ash, gross energy.

Posthatching development of the gastrointestinal tract (GIT) in various avian species has received relatively little attention (Latimer 1924; Kaufman 1927). More recently, it has been studied especially in connection with growth rates and performance of domesticated avian species and with their food utilization (Doskočil 1966, 1967). It was found, for instance, that the GIT of chickens grew rapidly in the first posthatching week with the small intestine increasing its mass by more than six times in this period (Baranyiova 1972ab), and that the chemical composition of their gastrointestinal tract may be affected by feeding schedules (D oskočil 1966, 1967).

Similar observations have been reported for the duck (Mahelka 1968). However, the chemical composition of their digestive organs has not been studied as yet. This fact prompted us to investigate the changes in composition of the individual digestive organs in this economically important avian species during the two posthatching months.

\section{Material and Methods}

Ninety White Pekin ducks aged 1 to 56 days were used in the experiment. They were reared in rearing houses and fed the Czechoslovak standard commercial feed mixtures for ducks (VKCH 1 and 2 ). 
The analyses were carried out at weekly intervals, using invariably $10 \mathrm{birds}$. They were weighed and killed by asphyxiation. The bodies were cut open, and the digestive organs were removed. The esophagus plus crop, proventriculus, gizzard and the intestines of each duckling were cut lengthwise, cleaned of the contents and weighed. The tissue samples were then dried to constant mass at $90-95^{\circ} \mathrm{C}$ for 24 hours. The individual chemical components were determined in dry matter using always 2 parallel samples: total nitrogen by a micromethod (Conway 1957), fat by $24 \mathrm{~h}$ petroleum-ether extraction (Montemurro and Stevenson 1960). For ash determination, the samples were combusted in an electric oven at $500^{\circ} \mathrm{C}$ for $24 \mathrm{~h}$, then sprinkled with $0.3 \mathrm{ml} 30 \%$ $\mathrm{H}_{2} \mathrm{O}_{2}$ and combusted for another $24 \mathrm{~h}$. The water content of the samples was calculated from the difference between wet mass and dry matter mass. Gross energy content of the GIT and liver was calculated from the amounts of protein $(23.9 \mathrm{~kJ}$ in $1 \mathrm{~g})$, fat $(39.4 \mathrm{~kJ}$ in $1 \mathrm{~g})$, and glycogen $(17.5 \mathrm{~kJ}$ in $1 \mathrm{~g}$ ). Clycogen energy content of the duck liver was calculated using our earlier data (B a ranyiová and Holub 1971).

The results were evaluated by Student's t-test.

\section{Results}

The live body mass of ducklings increased 45 times in 56 days from $54 \pm 2$ to $2414 \pm 205 \mathrm{~g}$. Its greatest actual increase was observed in the fifth week after

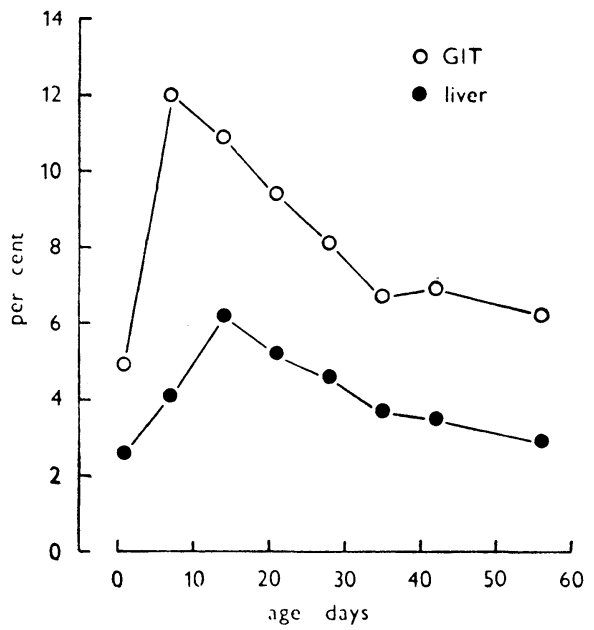

hatching $\left(64.3 \mathrm{~g} \cdot \mathrm{d}^{-1}\right)$.

During the same period, their GIT mass increased almost 56 times, from $2.7 \pm 0.1$ to $150.2 \pm 5.8 \mathrm{~g}$, and their liver mass increased more than 50 times, from $1.4 \pm 0.1$ to $70.6 \pm 5.6 \mathrm{~g}$. Thus the liver and especially the GIT mass grew more rapidly than the live body mass. The GIT mass grew most rapidly in the third week, that of the liver in the second week, i. e. earlier than both the GIT and live body mass (Table 1 ).

On day 1 after hatching the contribution of the GIT to the live body mass

Fig. 1. Contribution of the GIT and liver to the live body mass of ducks aged 1 to 56 days.

Table 1

Live body mass, GIT mass and liver mass of ducks aged 1 to 56 days

\begin{tabular}{|c|c|c|c|}
\hline Age & $\begin{array}{l}\text { Live body mass } \\
\mathbf{g}\end{array}$ & $\underset{\mathrm{g}}{\mathrm{GIT} \text { mass }}$ & $\begin{array}{l}\text { Liver mass } \\
\mathrm{g}\end{array}$ \\
\hline $\begin{array}{r}1 \\
7 \\
14 \\
21 \\
28 \\
35 \\
42 \\
56\end{array}$ & 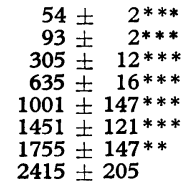 & $\begin{array}{r}2.7 \pm 0.1 * * * \\
11.2 \pm 0.4^{* * *} \\
33.2 \pm 1.2^{* * *} \\
59.5 \pm 1.5^{* * *} \\
80.6 \pm 3.1^{* *} \\
97.2 \pm 3.2^{* * *} \\
122.8 \pm 3.7^{* * *} \\
150.2 \pm 5.8\end{array}$ & $\begin{array}{r}1.4 \pm 0.1 * * * \\
3.8 \pm 0.2^{* * *} \\
18.8 \pm 1.4^{* * *} \\
32.9 \pm 1.0^{* * *} \\
46.0 \pm 2.8 \\
53.6 \pm 2.3^{*} \\
61.1 \pm 2.0 \\
70.6 \pm 5.6\end{array}$ \\
\hline
\end{tabular}

Values are means \pm S.E.M.

$\begin{array}{rl}* * * & P<0.001 \\ * * & P<0.01\end{array}$

** $P<0.01$

* $P<0.05$ (significantly different from the value obtained at the subsequent collection) 
of ducklings was lowest $(5.0 \pm 0.2 \%)$. During the first week it rapidly increased so that on day 7 it reached a maximum $(12.0 \pm 0.2 \%)$. Similarly, the contribution of the liver was smallest on day $1(2.6 \pm 0.1 \%)$, increased thereafter reaching a peak on day $14(6.2 \pm 0.3 \%$ ) (Fig. 1).

The actual water amount of the GIT increased 48 times by day 56 (from 2.2. \pm 0.1 to $103.0 \pm 33.5 \mathrm{~g}$ ). The protein amount increased even more, namely 59 times (from $0.4 \pm 0.1$ to $22.0 \pm 1.2 \mathrm{~g}$ ), the fat amount only 19 times (from $0.2 \pm 0.0$ to $3.9 \pm 0.6 \mathrm{~g}$ ), the ash content showed a 30 fold increase (from $0.03 \pm$ \pm 0.00 to $0.85 \pm 0.20 \mathrm{~g}$ ).

\section{Esophagus and crop}

The actual mass of the esophagus plus crop increased 12 times in the first two posthatching weeks from $0.2 \pm 0.0$ to $2.4 \pm 0.1 \mathrm{~g}$. Then it increased at a slower rate until day 42 . The contribution of these organs to the GIT mass was greatest on day 1 and decreased progressively thereafter (Table 2).

Table 2

Mass and chemical composition of the esophagus and crop of ducks aged 1 to 56 days

\begin{tabular}{|c|c|c|c|c|c|}
\hline$\underset{\mathrm{d}}{\text { Age }}$ & $\begin{array}{l}\text { Actual mass } \\
\mathbf{g}\end{array}$ & $\begin{array}{l}\text { Water } \\
\text { g }\end{array}$ & $\begin{array}{l}\text { Protein } \\
\quad \mathrm{g}\end{array}$ & $\begin{array}{c}\text { Fat } \\
\text { g }\end{array}$ & $\underset{\mathrm{g}}{\mathrm{Ash}}$ \\
\hline $\begin{array}{r}1 \\
7 \\
14 \\
21 \\
28 \\
35 \\
42 \\
49 \\
56\end{array}$ & $\begin{array}{l}0.2 \pm 0.0^{* * *} \\
0.8 \pm 0.0^{* * *} \\
2.4 \pm 0.1 * * * \\
4.2 \pm 0.2^{* *} \\
5.5 \pm 0.3^{* * *} \\
7.3 \pm 0.3^{* * *} \\
9.3 \pm 0.4 \\
9.7 \pm 0.5 \\
11.1 \pm 0.6\end{array}$ & $\begin{array}{l}0.19 \pm 0.00^{* * *} \\
0.63 \pm 0.10^{* * *} \\
1.91 \pm 0.10^{* * *} \\
3.24 \pm 0.10^{* * *} \\
4.25 \pm 0.20^{* * *} \\
5.78 \pm 0.20^{* * *} \\
7.53 \pm 0.30 \\
7.80 \pm 0.50 \\
8.90 \pm 0.50\end{array}$ & $\begin{array}{l}0.04 \pm 0.00 \\
0.13 \pm 0.00 \\
0.36 \pm 0.00 \\
0.75 \pm 0.00 \\
0.82 \pm 0.15^{* *} \\
1.05 \pm 0.04 \\
1.10 \pm 0.04^{* *} \\
1.30 \pm 0.06^{* *} \\
1.66 \pm 0.09\end{array}$ & $\begin{array}{l}0.12 \pm 0.00 \\
0.02 \pm 0.00 \\
0.05 \pm 0.00 \\
0.07 \pm 0.00 \\
0.14 \pm 0.02 \\
0.13 \pm 0.01 * \\
0.24 \pm 0.05 \\
0.22 \pm 0.03 \\
0.31 \pm 0.04\end{array}$ & $\begin{array}{l}0.01 \pm 0.00 \\
0.01 \pm 0.00 \\
0.02 \pm 0.00 \\
0.04 \pm 0.00 \\
0.04 \pm 0.01 \\
0.07 \pm 0.01 \\
0.08 \pm 0.01 \\
0.08 \pm 0.01 \\
0.07 \pm 0.01\end{array}$ \\
\hline
\end{tabular}

See footnotes to Table 1

The actual water content of the esophagus plus crop increased almost linearly from $0.2 \pm 0.01 \mathrm{~g}$ on day 1 to $8.9 \pm 0.5 \mathrm{~g}$ on day 56 . The relative hydration increased sharply between days 1 and 14 (from $75.6 \pm 1.0 \mathrm{~g}$ to $79.5 \pm 0.3 \mathrm{~g}$ ) and showed little change thereafter oscillating between $78.6 \pm 2.1$ and $81.0 \pm$ $\pm 0.6 \%$. The actual protein mass increased 41 times within the first two months of life, rising particularly from day 28 onwards. The relative protein content had a slightly downward trend. The actual fat mass increased 3 times to day 56, the relative fat content slightly increased between days 7 and 14. The actual ash mass of the esophagus plus crop increased 22 times in 56 days of posthatching life. The relative ash content was highest on day $1(1.4 \pm 0.0 \%)$ and decreased thereafter.

\section{Proventriculus}

On days 1 and 7 the proventriculus was analyzed together with the gizzard (Table 3). Their actual mass increased considerably during this period and their contribution to the GIT mass was highest on day 1. The actual mass of the proventriculus itself increased significantly from day 14 to day 42 . 


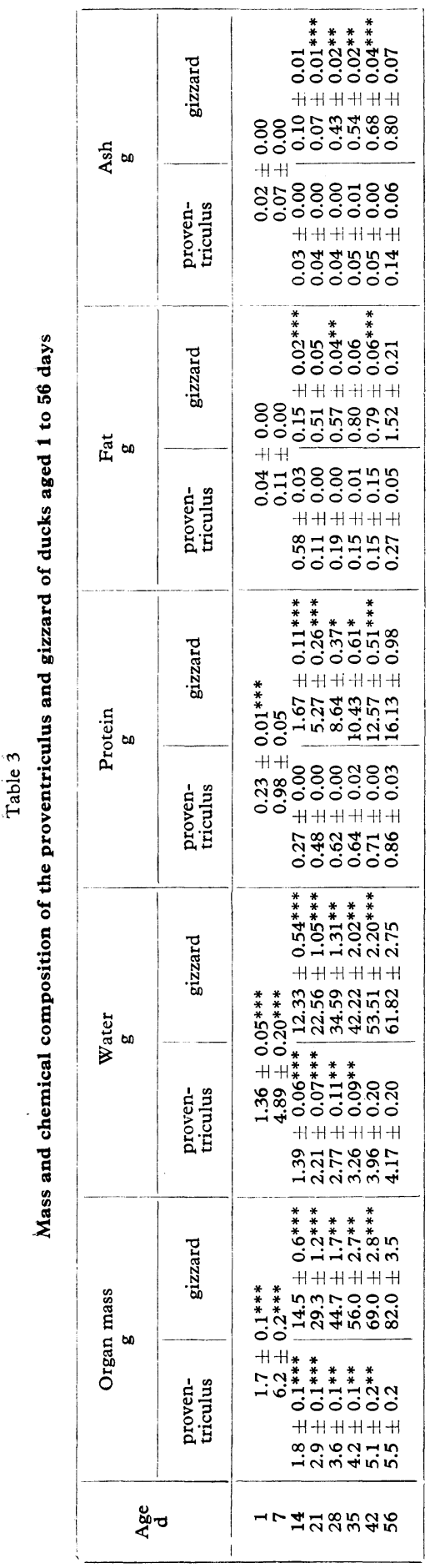

The actual mass of all chemical components showed an increase. The relative hydration of proventriculus, however, decreased form $81.0 \pm 0.4 \%$ to $76.0 \pm$ $\pm 1.3 \%$, most of this decrease occurring during the first 14 days. The relative protein content oscillated between $13.6 \pm$ \pm 0.4 and $16.7 \pm 1.0 \%$, the proportion of fat increased from $2.6 \pm 0.0$ to $4.9 \pm$ $\pm 0.9 \%$. The relative ash content oscillated between $1.0 \pm 0.1$ and $1.2 \pm 0.0 \%$.

\section{Gizzard}

The actual mass of this part of the GIT rose throughout the experimental period (Table 3) whereas its contribution to the GIT mass did not change appreciably after an initial drop in the first week.

The increase in the actual mass was especially sharp with water and protein; however, the relative hydration decreased from day 14 from $85.1 \pm 0.6$ to $75.2 \pm$ $\pm 0.6 \%$ on day 56 . The relative prctein content rose sharply between days 14 and 21 (from $11.5 \pm 0.5$ to $18.0 \pm$ $\pm 0.8 \%$ ). The relative fat content of the gizzard was more than one-half that found in the proventriculus. The actual fat content gradually increased from $0.04 \pm 0.0$ (day 1) to $1.52 \pm 0.21 \mathrm{~g}$ (day 56) (Table 3). After a slight increase between days 14 and 21 the relative ash content oscillated around $1 \%$.

\section{Intestine}

The actual mass of the intestine rose until day 42. Most of this increase, however, occurred in the first week when the initial mass increased 5.5 times (Table 4). Consequently, its contribution to the overall GIT mass increased from $28.5 \%$ on day 1 to $44.0 \%$ on day 14 .

The actual water content of the intestinal wall increased markedly, especially in the first three weeks of life. The relative hydration of the intestine oscillated only within very narrow limits, i.e. between $78.0 \pm 0.7$ and $80.4 \pm 0.3 \%$. The actual protein mass increased considerably in the third, and somewhat less 
Table 4

Mass and chemical composition of the intestine of ducks aged 1 to 56 days

\begin{tabular}{|c|c|c|c|c|c|}
\hline$\underset{\mathrm{d}}{\text { Age }}$ & $\begin{array}{c}\text { Organ mass } \\
\mathbf{g}\end{array}$ & $\begin{array}{c}\text { Water } \\
\mathrm{g}\end{array}$ & $\begin{array}{l}\text { Protein } \\
\mathrm{g}\end{array}$ & $\begin{array}{c}\text { Fat } \\
\mathrm{g}\end{array}$ & $\begin{array}{c}\text { Ash } \\
\mathrm{g}\end{array}$ \\
\hline $\begin{array}{r}1 \\
7 \\
14 \\
21 \\
28 \\
35 \\
42 \\
49 \\
56\end{array}$ & $\begin{aligned} 0.76 & \pm 0.05^{* * *} \\
4.16 & \pm 0.22^{* * *} \\
14.6 \pm 0.52^{* * *} & \pm 0.76^{* * *} \\
23.2 \pm 0 & \pm 0.9 \pm 1.49^{*} \\
27.9 \pm 1.9 & \pm 10 \\
29.8 & \pm 0.85^{*} \\
39.3 \pm 1.10 & \pm 1.67 \\
40.7 \pm 1.88 & \end{aligned}$ & $\begin{array}{l}0.60 \pm 0.03^{* * *} \\
3.32 \pm 0.18^{* * *} \\
13.01 \pm 0.49^{* * *} \\
18.37 \pm 0.60^{* *} \\
21.99 \pm 1,18 \\
23.32 \pm 0.70^{* * *} \\
31.60 \pm 0.94 \\
31.77 \pm 1.30 \\
35.02 \pm 1.37\end{array}$ & $\begin{array}{l}0.10 \pm 0.00 \\
0.58 \pm 0.00 \\
0.93 \pm 0.04^{* * *} \\
3.18 \pm 0.14^{*} \\
3.64 \pm 0.14^{* *} \\
4.29 \pm 0.17^{* * *} \\
5.44 \pm 0.15 \\
5.12 \pm 0.22 \\
5.53 \pm 0.57\end{array}$ & $\begin{array}{l}0.04 \pm 0.00 \\
0.14 \pm 0.00 \\
0.31 \pm 0.01^{* * *} \\
0.93 \pm 0.04^{*} \\
1.22 \pm 0.11 \\
1.18 \pm 0.10 \\
1.15 \pm 0.08^{*} \\
1.47 \pm 0.14^{*} \\
2.30 \pm 0.41\end{array}$ & $\begin{array}{l}0.01 \pm 0.00 \\
0.51 \pm 0.00 \\
0.09 \pm 0.00 \\
0.19 \pm 0.01 \\
0.22 \pm 0.01 \\
0.21 \pm 0.01 * * \\
0.30 \pm 0.02 \\
0.28 \pm 0.02 \\
0.30 \pm 0.01\end{array}$ \\
\hline
\end{tabular}

See footnotes to Table 1

in the fourth, fifth and sixth weeks. On the other hand, the relative protein content oscillated between $12.5 \pm 1.4$ and $14.6 \pm 0.2 \%$. The actual fat content increased considerably in the third week, less in the fourth, seventh and eight weeks. The relative fat content was highest after hatching $(5.9 \pm 0.0 \%)$, later it oscillated between $2.1 \pm 0.1$ and $4.4 \pm 0.6 \%$. The actual ash content of the intestine increased significantly only in the sixth week (Table 4); the relative ash content was highest on days 1 and $7(1.2 \pm 0.0 \%)$, thereafter it slightly decreased and oscillated about $0.7 \%$ until the end of the experiment.

\section{Liver}

The actual liver mass doubled in the first week and the actual water content increased as many as 3.5 times (Table 1). The relative hydration of the liver increased from $60.5 \pm 0.7$ to $75.0 \pm 0.4 \%$ and remained at this level until day 56 . The actual protein content rose from $0.2 \pm 0.0 \mathrm{~g}$ (day 1) to $11.2 \pm 1.2 \mathrm{~g}$ (day 56). The relative protein content increased slightly from $12.0 \pm 2.0 \%$ on day 1 to $17.0 \pm 0.5 \%$ on day 21 , and it oscillated about this value until day 56 . The actual fat content of the liver decreased in the first week, and rose between days 14 and 35 again. During the first posthatching week its relative content decreased from $21.6 \pm 0.1$ on day 1 to $5.1 \pm 0.01 \%$ (i.e. 6 times), and continued to decline until day 56 , reaching $2.2 \pm 0.1 \%$. The actual ash content rose 48.5 times whereas the relative one showed almost no changes during the experimental period (Table 5).

Table 5

Chemical composition of the liver of ducks aged 1 to 56 days

\begin{tabular}{|c|c|c|c|c|}
$\begin{array}{c}\text { Age } \\
\mathrm{d}\end{array}$ & $\begin{array}{c}\text { Water } \\
\mathrm{g}\end{array}$ & $\begin{array}{c}\text { Protein } \\
\mathrm{g}\end{array}$ & $\begin{array}{c}\text { Fat } \\
\mathrm{g}\end{array}$ & $\begin{array}{c}\text { Ash } \\
\mathrm{g}\end{array}$ \\
\hline 1 & $0.85 \pm 0.04^{* * *}$ & $0.17 \pm 0.03$ & $0.30 \pm 0.00^{* * *}$ & $0.02 \pm 0.00$ \\
7 & $2.80 \pm 0.15^{* * *}$ & $0.58 \pm 0.03$ & $0.19 \pm 0.00$ & $0.51 \pm 0.00$ \\
14 & $14.09 \pm 1.02^{* * *}$ & $2.88 \pm 0.18^{* * *}$ & $0.80 \pm 0.13$ & $0.26 \pm 0.04^{* *}$ \\
21 & $24.77 \pm 0.86^{* * *}$ & $5.58 \pm 0.16^{* *}$ & $1.17 \pm 0.15 * *$ & $0.38 \pm 0.01^{* *}$ \\
28 & $34.61 \pm 2.15$ & $7.25 \pm 0.51^{*}$ & $1.77 \pm 0.13$ & $0.54 \pm 0.06$ \\
35 & $39.11 \pm 1.49^{* *}$ & $9.23 \pm 0.55$ & $1.43 \pm 0.12$ & 0.03 \\
$\mathbf{4 2}$ & $49.38 \pm 1.66$ & $10.36 \pm 0.30$ & $1.48 \pm 0.08$ & $0.72 \pm 0.02$ \\
49 & $48.39 \pm 1.88$ & $11.40 \pm 0.51$ & $1.55 \pm 0.03$ & $0.77 \pm 0.03$ \\
56 & $53.05 \pm 4.18$ & $11.22 \pm 1.15$ & 0.05 & 0.04 \\
\hline
\end{tabular}


Gross energy of the GIT and liver

The actual amount of gross energy in the GIT organs rose from $17.3 \mathrm{~kJ}$ on day 1 to $678.6 \mathrm{~kJ}$ on day 56, i.e. 39.2 times. The energy of proteins accounted for $8.9 \mathrm{~kJ}$ in newly hatched ducklings, and rose to $524.0 \mathrm{~kJ}$ at the end of the experiment, i.e. it increased 58.9 times. The fat energy rose from $8.4 \mathrm{~kJ}$ to $154.6 \mathrm{~kJ}$ during the same period, i.e. it increased only 18.4 times (Table 6 ). Thus the proportions of protein energy and fat energy were almost equal in newly hatched birds but then changed entirely so that by day 56 the fat energy contribution dropped to $22.8 \%$, i.e. by more than one-half the original value (Fig. 2).

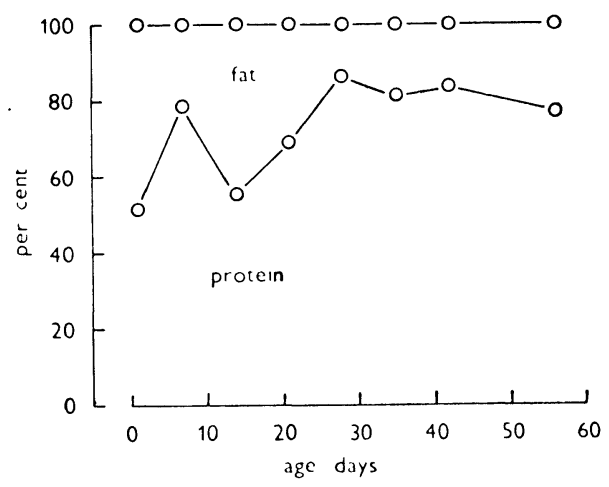

Fig. 2. Gross energy content in the GIT of ducks aged 1 to 56 days.

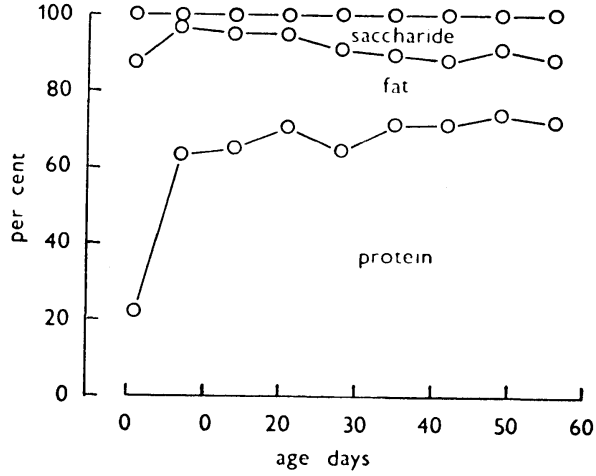

Fig. 3. Gross energy content in the liver of ducks aged 1 to 56 days.

Table 6

Gross energy in the GIT and liver of ducks aged 1 to 56 days

\begin{tabular}{|c|c|c|c|c|c|c|c|}
\hline \multirow{2}{*}{$\begin{array}{c}\text { Age } \\
\text { d }\end{array}$} & \multicolumn{3}{|c|}{ GIT } & \multicolumn{4}{|c|}{ Liver } \\
\hline & Fat kJ & Protein kJ & Total kJ & Fat kJ & Protein kJ & Glycogen kJ & Total kJ \\
\hline $\begin{array}{r}1 \\
7 \\
14 \\
21 \\
28 \\
35 \\
42 \\
56\end{array}$ & $\begin{array}{r}8.4 \\
9.5 \\
37.8 \\
42.4 \\
51.7 \\
89.8 \\
92.5 \\
154.6\end{array}$ & $\begin{array}{r}8.9 \\
35.0 \\
46.8 \\
95.7 \\
327.8 \\
391.4 \\
474.6 \\
524.0\end{array}$ & $\begin{array}{r}17.3 \\
44.5 \\
84.6 \\
138.2 \\
379.5 \\
481.2 \\
567.1 \\
678.6\end{array}$ & $\begin{array}{r}11.9 \\
7.6 \\
31.8 \\
46.5 \\
70.4 \\
56.8 \\
58.8 \\
62.8\end{array}$ & $\begin{array}{r}4.1 \\
13.8 \\
68.7 \\
133.1 \\
173.0 \\
220.2 \\
247.2 \\
267.7\end{array}$ & $\begin{array}{r}2.3 \\
0.7 \\
5.5 \\
9.8 \\
24.6 \\
32.2 \\
41.0 \\
42.5\end{array}$ & $\begin{array}{r}18.3 \\
22.1 \\
106.0 \\
189.4 \\
268.0 \\
309.2 \\
347.0 \\
373.0\end{array}$ \\
\hline
\end{tabular}

The actual gross energy content of the liver rose from $18.3 \mathrm{~kJ}$ on day 1 to $373.0 \mathrm{~kJ}$ on day 56, i.e. it increased 20.4 times (Table 6). The protein energy accounted for $4.1 \mathrm{~kJ}$ on day 1 and $267.7 \mathrm{~kJ}$ on day 56 presenting a 65.3 fold increase. The fat energy was $11.9 \mathrm{~kJ}$ on day 1 ; by the end of the first week it was considerably lower. Later it rose again but at a rate much slower than the protein energy content so that on day 56 it accounted for only $62.8 \mathrm{~kJ}$ (i.e. a 5.3 fold increase). From the data reported previously (Baranyiová and Holub 1971) we also calculated the energy content of liver carbohydrates in ducks; these provided $2.3 \mathrm{~kJ}$ on day 1 and $42.4 \mathrm{~kJ}$ on day 56, presenting an 18.6 fold increase (Fig. 3). 


\section{Discussion}

The growth rates of the GIT and liver in the duck change considerably during the first 8 posthatching weeks as demonstrated by the present data. This fact is documented by their changing contributions to the live body mass (Mahelka 1968; Baranyiová et al. 1980) but also by comparison with the mallard (Anas platyrhynchos) in which the live body mass as well as that of the GIT and liver increase at a slower rate (Mahelka 1973).

In birds, there are well-known great interspecies differences in posthatching GIT growth rate. They result, no doubt, from nutritional differences in hatchlings. Thus, e.g. in intensively fed pigeons a 38-fold increase in GIT mass was observed from hatching until 4 weeks of age (Ka fman 1927). Direct experimental evidence concerning the effect of nutrition upon the GIT immediately after hatching has been presented in chickens (Baranyiová $1972 \mathrm{ab}$ ).

In ducklings as in chickens (Baranyiová $1972 \mathrm{ab}$ ) or goslings (Knutsson et al. 1980; Knutsson and Sperber 1981), the GIT and liver growth rates surpass that of the live body mass: the GIT by about $20 \%$, and the liver by $22 \%$. The smallest contribution to this rapid growth rate was by the esophagus plus crop, a somewhat greater contribution was by the proventriculus followed by the gizzard, and the greatest was that of the intestine which increased its mass by $27 \%$ more than the esophagus plus crop.

Even with considerable increases in mass and thus in actual content of the individual chemical components the relative water and protein content of the GIT remained relatively constant; any changes that occurred were observed in the first and second posthatching weeks. When compared with chickens (Doskočil 1966, 1967) the esophagus and crop of newly hatched ducklings contain relatively less water and protein but more fat whose relative content is higher also in the intestinal wall.

These facts may also be affected by factors involved in water status of newly hatched birds (Tullett and Burton 1982), and in redistribution of their body fat in the course of hatching (Holman 1969; Baranyiová and Holman 1972).

In ducks the chemical composition of the liver is changing in a way similar to that found in chickens (Doskočil 1966, 1967) except that their liver hydration is lower than in chickens. On the other hand, the fat content in ducks is twice that found in chickens. During the first posthatching week, as evidenced also by Evans (1972), it declines to about one third of the original value. A similar trend has been described also in chickens (Doskočil 1966, 1967; Baranyiová and Holman 1972). During the same period, the liver glycogen stores decline to almost one third (Baranyiová and Holub 1971).

The chemical composition of the GIT of ducks in the first two months after hatching is characterized by a relatively high water content of the esophagus and crop, a high protein content of the gizzard and in the first week, a sharp decline of fat content in the intestine and liver.

Of interest are the changes in gross energy of the GIT and liver mass. The contribution of the GIT to the energy content increased from less than one-half on day 1 to almost two thirds on day 56. The contribution of the liver changed reciprocally. This change is accounted for by a small increase in the fat content of the liver. Neither the glycogen content of the liver rose in parallel to its mass; the glycogen increment was by more than three fifths smaller.

These data on gross energy in the liver indicate that in spite of relative increase 
of energy metabolism in the duck during the first posthatching week and its continued actual growth (Romijn and Lokhorst 1964; Romijn and Vreugdenhil 1969; Kotrbáček 1972) this organ becomes less important as a readily available energy reserve with advancing age.

\section{Změny hmotnosti a chemického složení gastrointestinálního traktu a jater kachen v prvých dvou měsících života}

$\mathrm{Na} 90$ kachňatech plemene bílého pekingského jsme sledovali změny hmotnosti a chemického složení jednotlivých částí GIT a jater od vylíhnutí do stáří 56 dní. Absolutní hmotnost GIT roste nejrychleji v týdnu třetím, jater v druhém, což vede ke zvyšování jejich podílů na živé hmotnosti. Na tomto růstu se u GIT nejvíce podílí střevo, potom žaludky, nejméně jícen a vole.

Při velkém zvyšování hmotnosti GIT zůstává jeho relativní obsah vody a bílkovin dosti stálý, obsah tuku, a to zvlášt ve střevě a v játrech se během prvého týdne prudce snižuje.

Bruttoenergie $(\mathrm{BE}) \mathrm{v}$ hmotě sledovaných orgánů absolutně, a to značně rozdílně, stoupá; v GIT téměř $40 \mathrm{krá}$, $\mathrm{v}$ játrech však jen $20 \mathrm{krát}$. U jater se na tomto malém nárůstu $\mathrm{BE}$ rozhodujícím způsobem podílí především malý vzestup absolutního množství tuku, ale $\mathrm{i}$ glykogenu. $\mathrm{V}$ důsledku toho $\mathrm{s}$ přibývajícím věkem kachňat ztrácejí játra jako pohotová energetická rezerva na významu.

\section{Изменение массы и химического состава желудочно-кишечного тракта} и печени уток в первые два месяца жизни

На 90 утятах белой пекинской породы проводились исследования изменений массы и химического состава отдельных частей желудочно-кишечного тракта и печени после вылупливания до возраста 56 суток.

Абсолютная масса желудочно-кишечного тракта быстрее всего увеличивается в течение третей недели, у печени - в течение второй недели, что выливается в увеличении их доли в живой массе. В данном росте желудочно-кишечного тракта самая большая доля приходится на кишечник, желудок, меньше всего на пищевод и зоб.

При больчшом увеличении массы желудочно-кишечного тракта его относительное содержание воды и белков отличается сравнительным постоянством, содержание жиров, в особенности в кишечнике и печени, в течение первой недели резко понижается.

Суммарная энергия (BE) в массе исследуемых органов абсолютно, но с супеестенной разностью, повышается; в желудочно-кишечном тракте почти в 40 раз, однако в печени лишь 20 раз. Решающая дола в приведенном небольшом увеличении $\mathrm{BE}$ у печени приходится прежде всего на небольшое увеличение абсолютного количества жиров и гликогена. В результате этого с увеличивающимся возрастом утят печень в качестве активного энергетического резерва теряет свое значение. 


\section{References}

BARANYIOVÁ, E. - HOLUB, A.: Age changes of liver and muscle glycogen contents of ducklings in the first two months of life. Acta vet. Brno, 40, 1971:273-278.

BARANYIOVÁ, E.: Vplyv príjmu potravy a hladovania na rozmery tráviaceho traktu a na obsah glycidov v tele deutektomovaných a intaktných kurčiat. Ph.D. thesis, Brno, 1972a, 198 pp.

BARANYIOVÁ, E.: Influence of deutectomy, food intake and fasting on the digestive tract dimensions in chickens after hatching. Acta vet. Brno, 41, 1972b: $373-384$.

BARANYIOVÁ, E. - HOLMAN, J.: Lipid droplets in hepatocytes of chicken embryos and chickens after hatching. Acta vet. Brno, 41, 1972: 367-372.

BARANYIOVÁ, E. - HOLUB, A. - PONÍŽILOVÁ, E.: Age-dependent changes in body composition of ducks in the postincubation period. Proc. Int. Union of Physiol. Sciences, XIV, 1980: 312.

CONWAY, E. J.: Microdiffusion analysis and volumetric error. London 1957, 465 p.

DOSKOČIL, J.: Vliv různé frekvence přijmu krmiva během dne na změny váhy a chemického složení kuřat plemene New Hampshire v postinkubačním údobí. Ph.D. thesis, Veterinární fakulta VŠZ, Brno, 1966, 276 pp.

DOSKOČIL, J.: Effect of different frequency of food intake of the weight and chemical composition of body and gastrointestinal tract in chickens. Acta Univ. Agric. B, 36, 1967: 429-437.

EVANS, A. J.: Fat accretion during postembryonic growth in the domestic duck, with additional data from the mallard. Physiol. Zool., 45, 1972: 167-177.

HOLMAN, J.: Occurrence and ultrastructure of lipid droplets in the developing chick intestinal epithelium. Acta anat. 74, 1969: 54-64.

KAUFMAN, L.: Recherches sur la Croissance du Corps et des Organes du Pigeon. Biol. gen., 3, 1927: $105-129$.

KOTRBÁČEK, V.: Age-dependent changes in $\mathrm{O}_{2}$ consumption and $\mathrm{CO}_{2}$ production of Pekin ducks from hatch to 60 days of age at different ambient temperatures. Acta vet. Brno, 42, 1973: $15-21$.

KNUTSSON, P. G. - SPERBER, I. - LILJA, C.: Organ development and growth rate in geese and quail. Proc. Int. Union of Physiol. Sciences, XIV, 1980: 468.

KNUTSSON,P. G. - SPERBER, I.: Thoughts about the relations between organ development and body growth. Papers dedicated to Professor Johannes Moustgaard. The Royal Danish Agricultural Society, Copenhagen, 1981, pp. 172-177.

LATIMER, H. B.: Postnatal growth of the body, systems, and organs of the single-comb White Leghorn chicken. J. Agr. Res., 29, 1924: 363-397.

MAHELKA, B.: Růst orgánů trávící soustavy u kachny domácí (pekingské). Acta Univ. Agric. A, 16, 1968: 337-343.

MAHELKA, B.: Zum Vergleich des postnatalen Wachstums und der Entwicklung der Wildund Hausente. Acta Sc. Nat. Brno, 7, 1973: 1-50.

MONTEMURRO, D. G. - STEVENSON, A. F.: Survival and body composition of normal and hypothalamic obese rats in acute starvation. Am. J. Physiol., 198, 1960: 757-761.

ROMIJN, C. - LOKHORST, W.: Some aspects of poultry metabolism. Zbl. Vet. Med. A, 11, 1964: $297-314$.

ROMIJN, C. - VREUGDENHIL: Energy balance and heat regulation in the White Leghorn fowl. Neth. J. vet. Sci., 2, 1969: 32-58.

TULLETT, S. G. - BURTON, F. G.: Factors affecting the weight and water status of the chick at hatch. Br. Poult. Sci., 23, 1982: 361-369. 